\title{
Student Learning in Economic Education Study Programs Using Sharia-Based Sharia Economics Textbooks
}

\author{
M W Fandyansari and P V Sefaverdiana \\ Economic Education Department, IKIP Budi Utomo, Indonesia
}

\begin{abstract}
The preparation or development of Islamic economics textbooks is based on the fact that this Islamic economics course is a compulsory subject but books or teaching materials that can facilitate and understand students are not yet available. The purpose of the preparation of this textbook is to compile books that are easy to understand and contain contents or material about Islamic economics but do not prevent students from understanding the material. The method used in this research is research and development using the model from Dick and Carrey, and in this study, the research procedure consisted of nine steps. The study was conducted on students of the IKIP Budi Utomo Economic Education Study Program class of 2016. The results of the study and the results of the validation of several experts are the Syariah-based Islamic economic textbooks included in the categories suitable for use.
\end{abstract}

Keywords: Islamic Economics, Student Learning, Sharia-Based

\section{Introduction}

In the midst of the rampant development of Indonesia towards the 4.0 era in all fields, especially information technology, education has become one of the lines that inevitably must go along to move forward in order to keep abreast of existing developments [1]. Primarily for universities, students are no longer only intended to be a learner who only masters the material that has been delivered by lecturers, but must also be able to master a variety of skills, ranging from soft skills, mastery of IT, mastery of several languages to be familiar with the main information technology social media. Even so, it cannot be denied that the quality of education is still below that of other countries, this is reinforced by the statement of the Indonesian Ministry of Education, M. Nasir said that "Indonesian higher education competition at the international level is still low because there are only three state universities that are ranked 500th in the world" [2]. One of Indonesian Ministry of Education's ways to encourage improvement in the quality of tertiary institutions in Indonesia is to cluster higher education institutions whose purpose is to improve quality and also become the basis for Indonesian Ministry of Education to develop and provide policies in accordance with each level of the higher education cluster. That is expected to encourage and improve the quality of education in Indonesia so that later more universities will advance and compete with other world universities. Indeed, the impact of the recent developments in science and technology has forced Indonesia to accelerate development and development in all aspects, including 
education. Unceasingly the government through the Ministry of Research, Technology and Higher Education has made various innovations to improve the quality of learning at the tertiary level of education.

In addition to the clusterization that is being intensified by the Ministry of Research and Technology, curriculum improvements are also one of the ways taken by the government to improve the quality of education. Indonesian National Qualification Framework (KKNI) is a curriculum that is expected to improve the quality of tertiary education graduates, which includes course competencies including cognitive, psychomotor and affective. With the three elements of competency, it is expected that students who will later have completed their studies can and are able to juxtapose, equalize, integrate the education sector, training, and work experience to be able to keep up with the demands of the field or the world of work. The KKNI was formed issued in Presidential Regulation Number 8 of 2012 and Law Number 12 of 2012 concerning Higher Education. In order for graduates from higher education to graduate in accordance with KKNI standards, the campus must follow the three stages of designing and compiling the KKNI curriculum, namely:

1. Curriculum planning stage. At this stage, curriculum preparation must really prepare CPL or graduate learning outcomes, the concept of composing courses and finally the formation of courses

2. The learning planning stage. The second stage is designing the learning process in one semester by determining learning outcomes in each course.

3. Program evaluation phase, namely the evaluation phase which is carried out periodically so that the quality of learning continues to improve.

Before the KKNI-based curriculum was promoted, in Indonesia a competency-based curriculum or $\mathrm{CBC}$ was applied. KBK is contained in Government Regulation Number 17 of 2010 Article 97. The implementation of the KBK at that time was expected to be carried out at the end of 2002 in all tertiary institutions, but in reality not all tertiary institutions applied the KBK curriculum due to various obstacles. And then in 2012 the government again issued new rules for implementing the latest curriculum, the KKNI. The implementation of the IQF through seven stages, namely: Establish a graduate profile:

1. Formulate learning outcomes

2. Formulate the competency of the study material

3. Mapping the learning outcomes of study material

4. Arrange the course

5. Develop a curriculum framework, and

6. Develop lecture plans

One of the stages that must be really well undertaken by a student so that later when completing lectures, a graduate can be as stated in the curriculum of KKNI is at the seventh stage, namely lectures. Every student must really be able to take part in lecturing activities and master various materials delivered by the instructor. In lectures, if there are obstacles that can reduce the effectiveness of lecture learning, it is a must for students to be able to avoid, discard and even find a way out so that the problems that occur can be resolved immediately. Either solved privately or together looking for solutions with teachers or lecturers. But it is not only the student's obligation, a lecturer or teacher must also be able to provide the best and maximum in the lecture process.

Although technology is currently developing rapidly and learning resources can be obtained from anywhere, textbooks remain a learning resource that is widely used in learning activities [3]. Even though it is still considered conventional, textbooks are still used because there are some materials that still need textbooks to make it easier for students to understand 
the material. In addition, textbooks are still considered a source of information in learning activities that have accurate information. In the Big Indonesian Dictionary, the book has a meaning as a bound sheet of paper and contains writing or without writing. While teaching is the basic word of learning. So that textbooks can be interpreted as books that are a form of science in the form of analysis of the curriculum in the form of writing.

Therefore, it can be concluded that the effects of gender representations in textbooks are influenced, inter alia, by students' cultural and social context [4]. In lectures, for new students, textbooks have the function to recognize, remember and apply the knowledge taught. As for advanced students, the book serves to prepare the synthesis and analysis of conducting research. In addition, life and scientific developments that continue to occur and very fast, causing a shift in the characteristics or models of learning, but textbooks remain a reference for students to become better in observing, asking, using reason, and communicating.

As happened in the Economic Education Study Program in Islamic economics courses. The majority of students are non-Muslims who lack mastery of terms in books on Islamic economics. In addition, in the many outstanding books, there are many quotations from the Qur'an that are not understood by students, which results in students lacking the enthusiasm to read or deepen about Islamic economics. So that lecturers or in this case researchers have the obligation to find a way out so that the difficulties faced by students related to textbooks or textbooks for learning Islamic economics courses can be resolved. This is because the world of education is a dynamic world, as dynamic as humans as subjects of learning in a variety of social, economic, cultural, political contexts that lie behind them all the time (Permendiknas Number 2 Chapter 1 on General Provisions, 2008). And at the IKIP Budi Utomo campus, it has distinctive learning, which is Rudeness. Kebudiutamaan has 5 important pillars namely Indonesia, Care, Utilization, Compliance, and Compliance. In general, Indonesian-ness in a large Indonesian dictionary has the meaning "to explain the things and conditions of Indonesia from various aspects, both geographical, religious, politic, cultural and historical" or reflected in the first principle of Pancasila, namely "Social Justice for all Indonesian people" [5]. The second pillar of virtue is care, which means that IKIP Budi Utomo has a concern for the world of education, for all Indonesian people from Sabang to Merauke by providing the broadest opportunity for those who wish to continue their education to tertiary level. There is no difference between the rich and the poor because all Indonesian children are entitled to an education. Utilization is the third pillar, which means that by providing the broadest or widest opportunities for Indonesian children who wish to continue their tertiary education, this is expected to be a manifestation of the benefits of the IKIP Budi Utomo campus for Indonesia in the world of education. Fourth, the pillar of virtue is compliance, that is, every citizen in acting and behaving must always be in the corridor of applicable law, both state law, customary law and religious law, so as not to violate the norms or laws prevailing in society. While the last pillar of propriety is a description of a person about who he is, for example, a student, the attitude and behavior in acting must reflect a student [5].

Based on the description, a sharia economics textbook was prepared in the hope that students participating in sharia economics courses could understand well the material on sharia economics and increase the application or application of that knowledge with values or the five pillars of Virtue.

The formulation of the problems in this study are: 1) how to compile a textbook of Islamic economics based on virtues for students of economic education, 2) how a textbook of Islamic economics based on virtue for economic education students can help students understand sharia economic material. While the objectives of conducting this textbook development research are to 1) compile a Syariah-based Islamic economics textbook for economic 
education students, 2) to make a sharia-based Syariah economics textbook for economic education students into books that can help students understand sharia economic material.

\section{Methods}

The research with the title "Development of Sharia-Based Economics Textbook for Economics Education Students" uses a research and development method. Research and development according to Borg and Gall (1983: 772) is "educational research and development is a process used to develop and validate educational products" [6]. While Seels and Richey (1994) define research and development as "a systematic study of the design, development, and evaluation of programs, processes and learning products that meet the validity, practical and effective criteria" [7]. This research was designed using Dick and Carey's instructional model. There are 10 steps or stages in the instructional model of Dick and Carey [8], but in this study only uses 9 steps, as shown below:

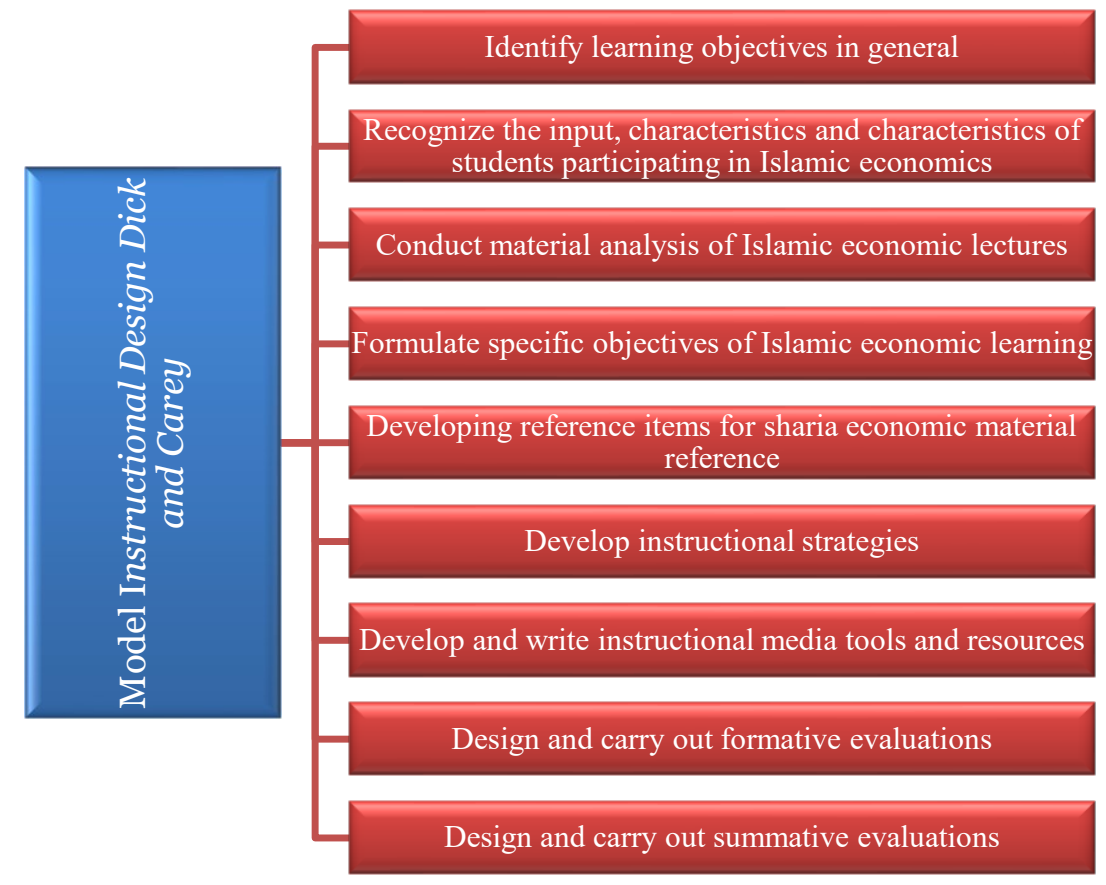

Fig 1. Stages of the Dick and Carey Instructional Model

The steps of the Dick and Carey model are similar as described by Syaodih regarding the research and development implementation procedures used, namely: 1) descriptive method, 2) evaluation method and 3) experimental method. Descriptive method is used in preliminary research to collect data about existing conditions, which include the condition of old or existing products as a comparison with new products, the condition of users such as students or lecturers, conditions of supporting factors or other inhibiting factors. The evaluation method is used to test the development of a new product, which has gone through various trials and at 
each trial evaluation is held. The experimental method is used to test the efficacy of the product produced [9].

The research was carried out at Campus C IKIP Budi Utomo located at Jalan Citandui number 46, Purwantoro Village, Blimbing District, Malang City. The study was conducted on students of the 2016 Class of Economic Education Study Program, amounting to 70 students.

Data collection instruments using a questionnaire instrument. In addition to collecting data from students, questionnaires are also used to obtain data from media experts, linguists, material experts, learning design experts, content experts, small-scale tests and joint scale tests with students.

\section{Results and Discussion}

The development of this textbook has nine steps which become the stages in its research as described above. Before testing the students, pretest and posttest have been conducted to find out the increase in the results of sharia economic lectures. At the time of the pretest the results obtained were $72.5 \%$ and after treatment using textbooks and the posttest test was obtained an average yield of $83.6 \%$. So as a whole it can be concluded that the textbook of Islamic economics based on the virtue that was developed is included in the category of feasible to use.

The material discussed in this textbook consists of five chapters, namely:

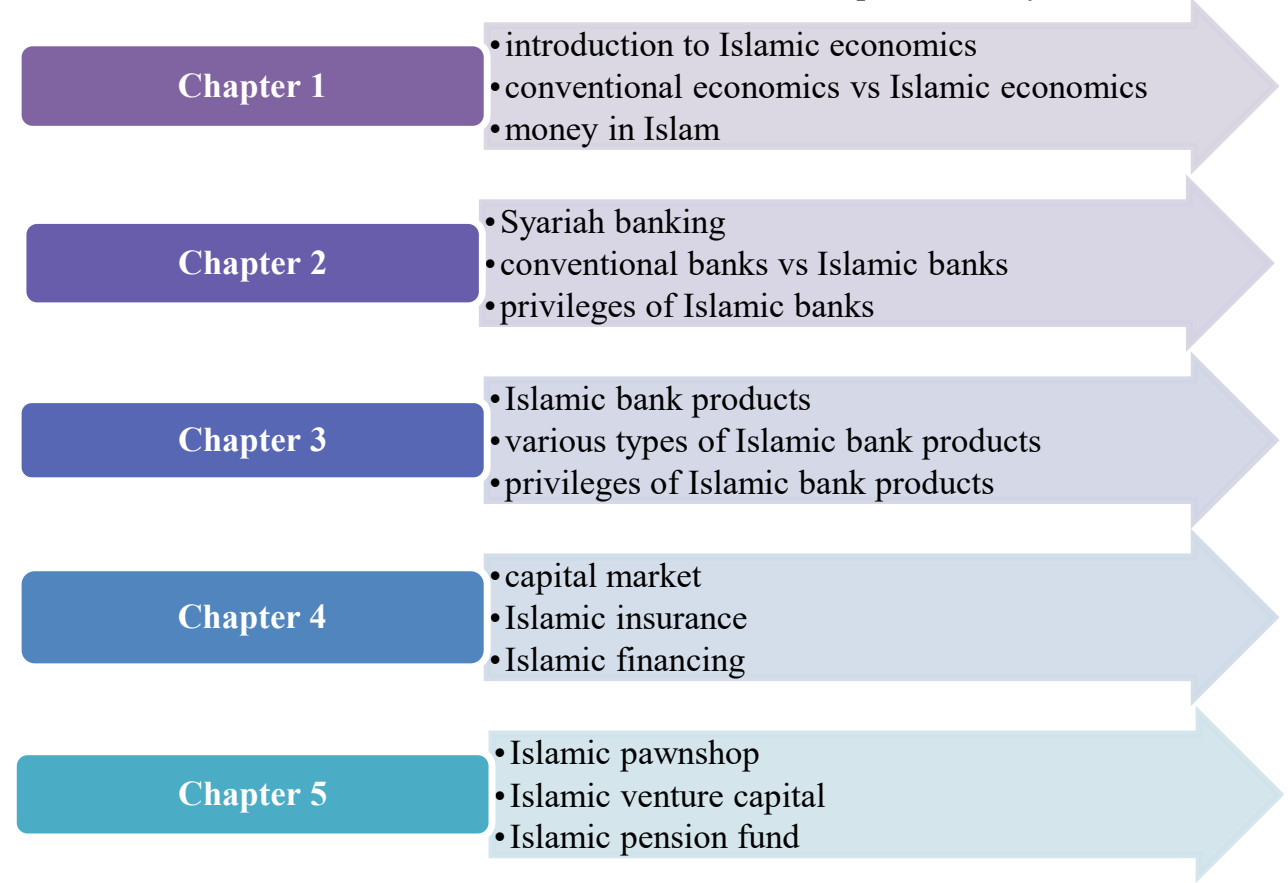

Fig 2. Chapter in the shariah textbooks

In addition to the five chapters above, on every discussion or every material, the reinforcement material is added about virtue that is the hallmark of IKIP Budi Utomo, and this virtue has five pillars which are discussed in each material, namely: 


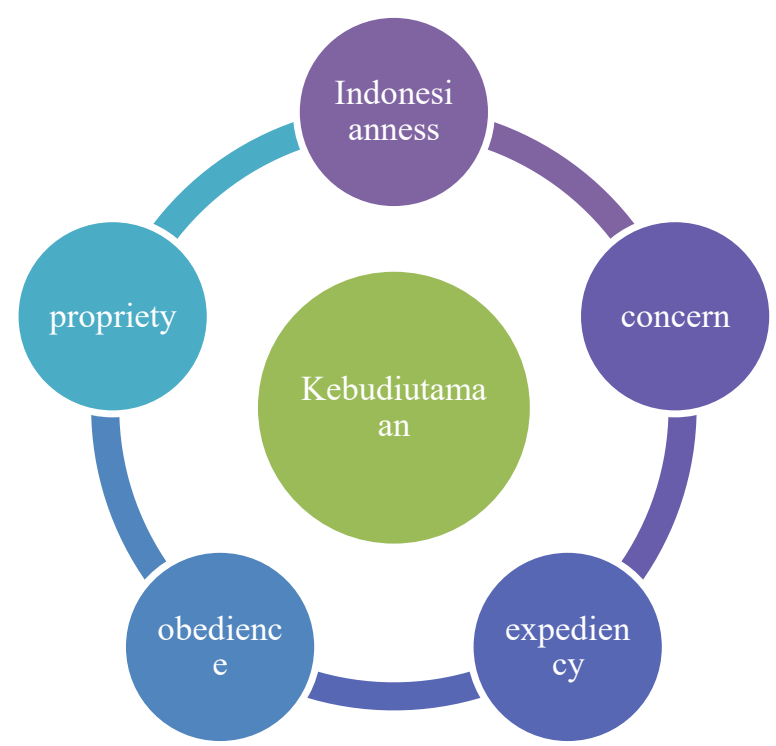

Fig 3. Five pillars in shariah textbooks

The results of this development research are in the form of Islamic economics textbooks which have been tested and validated by three expert namely material experts, media experts, and linguists. There are two material experts in this study, namely economics material experts and material matter experts. The selected shariah economics expert is a lecturer who has mastery in economics and has the Lector's academic rank and understands sharia economics, while the material matter expert is a lecturer with the academic position of the associate professor and has mastered the material on Virtue. From sharia economics material experts, the value of validation was $83.3 \%$, and the material expertise experts obtained test results of $75.2 \%$. The selected media experts are lecturers who have excellent mastery of learning, so they can provide excellent input and advice in validation activities in order to get good textbooks. From media experts, the test results were $78.6 \%$. The third expert is a linguist and is a lecturer who is an expert in the field of language, is a doctor in the field of Indonesian language and the academic position of the head lecturer, so that it can assess or validate this textbook in accordance with good Indonesian or in accordance with improved spelling. Linguists gave a test result of $81.7 \%$.

In addition to the three experts, this textbook has also been conducted twice on student tests, namely a small scale test and a large scale test. A small scale test was conducted involving 40 students of the 2016 class, while a large scale test involved 70 students. A small scale test is carried out by applying and testing the material of Chapters 1 and 2 and gets a response from students who are in good qualifications or equivalent to the percentage level of $82.6 \%$. Whereas a large-scale trial conducted on 70 students by examining the material in Chapters 4 and 5 got good results or equal to the percentage level of $86.3 \%$.

From the results of the pre-test and post-test, validation on several experts and small-scale and large-scale tests, it was found that the Islamic economics textbook based on Islamic economics is included in both criteria and is included in the appropriate category for use in Islamic economic lectures for students in economic education study programs.

As a country with the world largest Muslim citizens, the government of Indonesia has been integrating Islamic education in its school curriculum from elementary until senior high levels 
[10]. Since the opening of specialization professors and students have encountered several problems connected with learning, the main of which is insignificant availability of special literature. This is largely a consequence of underdevelopment of the scientific direction on the fundamentals of Islamic economics in Russia and lack of textbooks on the federal level [11]. In these circumstances, the University staff has prepared and published a series of educational publications, including textbooks, lectures, guidelines, covering all the main sections of Islamic economics and the economy of Islamic countries.

From the historical preview of economic in Islamic education, Ahmed points out that Islamic economics education is a distinctive blend of Shariah principles and conventional economics [12]. So, sharia economics textbooks as long as did not contradict with Islamic principles, they can be adopted or can be used in Islamic economics education. From this definition and the result of research can be shown that the Islamic economics textbook can be used for higher students in economic education programs.

\section{Conclusion}

From the results of the pre-test and post-test, validation on several experts and small-scale and large-scale tests, it was found that the Islamic economics textbook based on Islamic economics is included in both criteria and is included in the appropriate category for use in Islamic economic lectures for students in economic education study programs.

\section{References}

[1] M. Rüßmann et al., "Industry 4.0. The Future of Productivity and Growth in Manufacturing," Bost. Consult., no. April, pp. 1-5, 2015.

[2] OECD, PISA 2015 Results (Volume I): Excellence and Equity in Education. 2016.

[3] B. W. Truckman, Conducting Educational Research. New York: Harcourt Brace Jovanovic Inc, 1972.

[4] Y. Behnke, "Textbook Effects and Efficacy," in The Palgrave Handbook of Textbook Studies, no. February, E. Fuchs and A. Bock, Eds. Germany, 2018.

[5] P. P. Setyosari, Metode Penelitian Pendidikan \& Pengembangan. Jakarta: prenada media, 2013.

[6] W. R. Borg and M. D. Gall, Educational Research An Introduction. New York: Longman Publisher, 1983.

[7] B. B. Seels and R. C. Richey, Teknologi Pembelajaran: Definisi dan Kawasannya. Jakarta: Kerjasama IPTPI LPTK UNJ, 1994.

[8] W. Dick and L. Carey, The Systematic Design of Instruction. New York: Harper Collin Publishers, 1996

[9] Sugiyono, Metode Penelitian Kuantitatif, kualitatif dan R \& D. Bandung: Alfabeta, 2013.

[10] Suryani, "The significance of islamic economics study in discipline of modern economics," $J$. Indones. Econ. Bus., vol. 27, no. 1, pp. 111-121, 2012.

[11] A. Darmadji and Y. Ardiansyah, "Islamic Education Teachers' Content Knowledge of Islamic Law Matters : A Study in Yogyakarta City Ahmad Darmadji," Mediterr. J. Soc. Sci., vol. 6, no. 5, pp. 441-449, 2015.

[12] H. Ahmed, Theoretical foundations of Islamic economic. Jeddah: Islamic Development Bank, 2002. 